\title{
Tratamentul conservativ al empiemului subdural: o complicație a sinuzitei odontogene
}

\author{
Manuela Arbune ${ }^{1,2}$, Liliana Baroiu ${ }^{1,2}$, Teodora Marcu ${ }^{1,2}$, Mihaela Lungu ${ }^{1,3}$ \\ ${ }^{1}$ Facultatea de Medicină şi Farmacie, Universitatea „Dunărea de Jos", Galaţi, România \\ ${ }^{2}$ Spitalul Clinic de Boli Infecţioase, Galaţi, România \\ ${ }^{3}$ Spitalul Clinic Judeţean de Urgenţă, Galaţi, România
}

\begin{abstract}
REZUMAT
Infecţiile odontogene sunt factori predispozanţi pentru $10 \%$ dintre sinuzitele maxilare, rareori complicate cu meningite şi empiem subdural. Majoritatea empiemelor asociate infecţiilor dentare au etiologie polimicrobiană. Tratamentul standard cuprinde măsuri suportive, combinaţii de antibiotice şi drenaj chirurgical. Prezentăm un caz rar de empiem subdural apărut la un bărbat în vârstă de 20 de ani, cu infecţii odontogene neglijate. Evoluţia a fost favorabilă după tratament antibiotic, fără a impune intervenţia neurochirurgicală.
\end{abstract}

Cuvinte cheie: empiem subdural, infecţii odontogene, tratament antibiotic

\section{INTRODUCERE}

Empiemul subdural este o colecție purulentă localizată în spaţiul dintre dura mater şi arahnoidă (1). Factorii favorizanți pentru apariția empiemului subdural sunt focarele infecțioase de vecinătate, traumatismele craniene şi diseminarea hematogenă de la un focar infecțios situat extracranian (2). Etiologia variază în funcție de zona geografică, de sursa infecției, dar şi de caracteristicile pacientului, influențate de vârstă, status imun şi co-morbidităţi. Măsurile terapeutice principale sunt administrarea antibioticelor timp de 4-8 săptămâni şi corectarea hipertensiunii intracraniene. Intervențiile de excizie şi drenaj neurochirurgical sunt recomandate de urgență, dar pot fi temporizate în cazurile colecțiilor cu dimensiuni mici, constituite recent (3).

\section{PREZENTARE DE CAZ}

Pacient în vârstă de 20 de ani, din mediul urban, fumător, emigrat temporar în scop ocupațional, s-a prezentat la serviciul de urgenţă pentru cefalee frontală şi sindrom febril, cu debut de 10 zile. În ultimele 24 de ore s-au instalat brusc rinoree purulentă şi deficit senzitivo-motor al membrului superior stâng. Istoricul medical a evidenţiat repetate episoade de infecții respiratorii şi multiple probleme dentare neglijate, agravate în ultimile 3 luni, pentru care a luat automedicație cu antiinflamatorii nesteroidiene şi antibiotice, pe care nu le poate preciza.

Examenul clinic iniţial a evidențiat febră 390C, puls 95/min, frecvență respiratorie 24/min, TA 115/60 mmHg, pareza membrelor stângi şi sindrom meningian, scor Glasgow 15 şi scor qSOFA 0. Evaluarea de laborator evidențiază leucocitoză 14.260/ $\mathrm{mm}^{3}$ şi completează cele 4 criterii ale sindromului de răspuns inflamator sistemic. Alte modificări de laborator au fost sindromul inflamator biologic intens şi creşterea procalcitoninei peste $10 \mathrm{ng} / \mathrm{ml}$, semnificând asocierea sepsisului. Testele pentru HIV, VHB şi VHC şi lues au fost negative. 
Examenul computer tomografic cerebral (CTC) nativ a indicat uşoară lărgire a reliefului cortical parietal drept, imagini aerice multiple parietal drept, frontal drept şi în coasa creierului, cu sistem ventricular simetric şi dimensiuni normale, pansinuzită dreaptă şi sinuzită etmoidală stângă.

Lichidului cefalorahidian (LCR) a fost caracterizat de pleiocitoză $\left(450 / \mathrm{mm}^{3}\right)$ cu predominanța polimorfonuclearelor $(80 \%)$, albuminorahie crescută $(66 \mathrm{mg} / \mathrm{dL})$ şi glicorahia scăzută $(6,52 \mathrm{mg} / \mathrm{dL})$. Diagnosticul suspicionat a fost meningoencefalita bacteriană, dar etiologia nu a fost identificată. Examenul microscopic direct şi culturile realizate pe medii aerobe au fost negative. $\mathrm{Nu}$ au fost disponibile medii anaerobe pentru cultură.

Tratamentul antibiotic cu Meropenem a fost inițiat empiric, dar după 72 de ore a persistat febra şi s-a deteriorat neurologic, scorul Glasgow a scazut la 8 şi au apărut convulsii ale hemicorpului stâng. Evoluţia nefavorabilă a impus reluarea investigațiilor imagistice. Rezonanța magnetică (RMN) a evidențiat sinuzită cu localizări maxilar dreapt, sfenoidal şi frontal, dar şi o imagine de 2,5 mm, sugestivă pentru empiem subdural fronto-parietal drept (Fig. 1).

Planul terapeutic a fost revizuit, înlocuind Meronem cu asocierea Ceftriaxon, Vancomicin şi Metronidazol. Intervenția neurochirurgicală de drenaj al empiemului a fost temporizată. Evoluţia a fost favorabilă după tripla asociere de antibiotice, administrată timp de 21 de zile. Pacientul s-a externat la cerere, dar a revenit la control după o lună, când examenul clinic a fost normal, cu excepția problemelor dentare nerezolvate încă (Fig. 2).

\section{DISCUŢII}

Empiemul subdural poate complica $2 \%$ dintre meningitele bacteriene la adult (4) şi reprezintă $20 \%$ dintre supurațiile intracraniene localizate din practica neurochirurgicală. Prevalența empiemului subdural este mai crescută la bărbaţi şi la persoane din a doua şi a treia decadă de viață, concordant cu frecvența mai mare a otitelor şi sinuzitelor care apar la aceste vârste (5).

O metaanaliză realizată pe 51 de studii care au evaluat etiologia supurațiilor cerebrale localizate a cumulat 2653 de culturi din LCR, dintre care $30 \%$ au fost negative şi $26 \%$ polimicrobiene(6). Frecvența etiologiei polimicrobiene pare să fie mai mare, estimată la peste $50 \%$ dintre supurațiile cerebrale. Cele mai frecvente specii bacteriene izolate au fost: Streptococcus spp (36\%), Staphylococcus spp (17\%), Enterobacter spp (12\%), Bacteroides spp (7\%), Haemophilus spp (3\%), Peptostreptococcus spp (3\%), alte categorii (17\%) (4). Bacteriile anaerobe se asociază în majoritatea supurațiilor
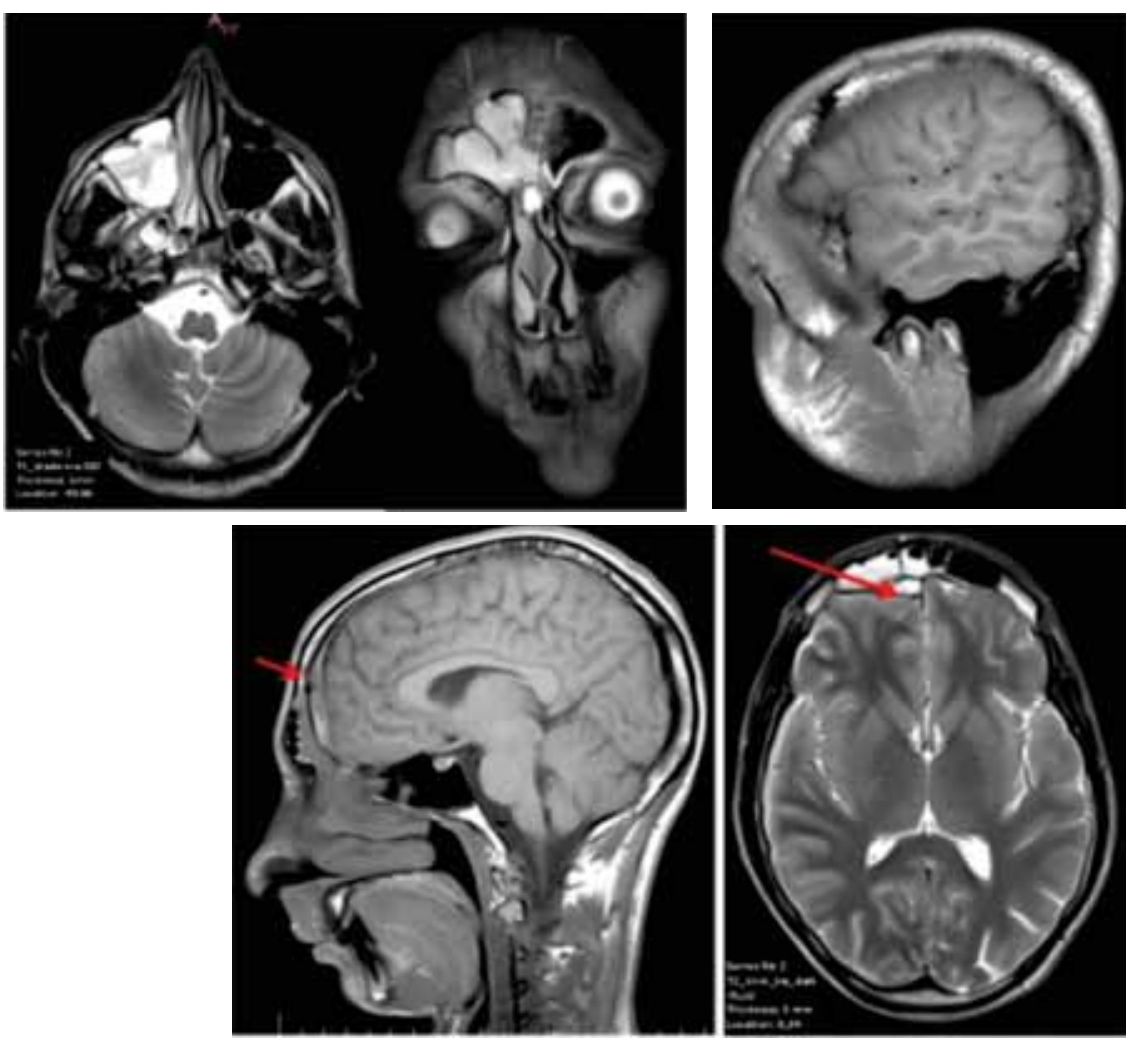

FIGURA 1. RMN cerebral $(a, b, c, d, e)$

Acumulare în hipersemnal T2 şi hiposemnal T1 diferit de cel al LCR, cu restricție pe secvența de difuzie, localizată subdural, fronto-parietal de partea dreaptă, cu grosime max. 2,5 $\mathrm{mm}$; administrarea substanței de contrast evidențiază enhancement puternic şi aspect îngroşat al structurilor meningeale convexitare de partea dreaptă; fără modificări de semnal, nativ şi postcontrast, la nivelul parenchimului cerebral infra şi supratentorial; sistem ventricular $\mathrm{cu}$ dimensiuni, formă şi topografie normale; mucoasa îngroşată, cu semnal intens T2 la nivelul sinusului maxilar drept, sfenoidal şi frontal, care asociază acumulări în hipersemnal T2 la nivelul sinusului maxilar drept şi frontal. 


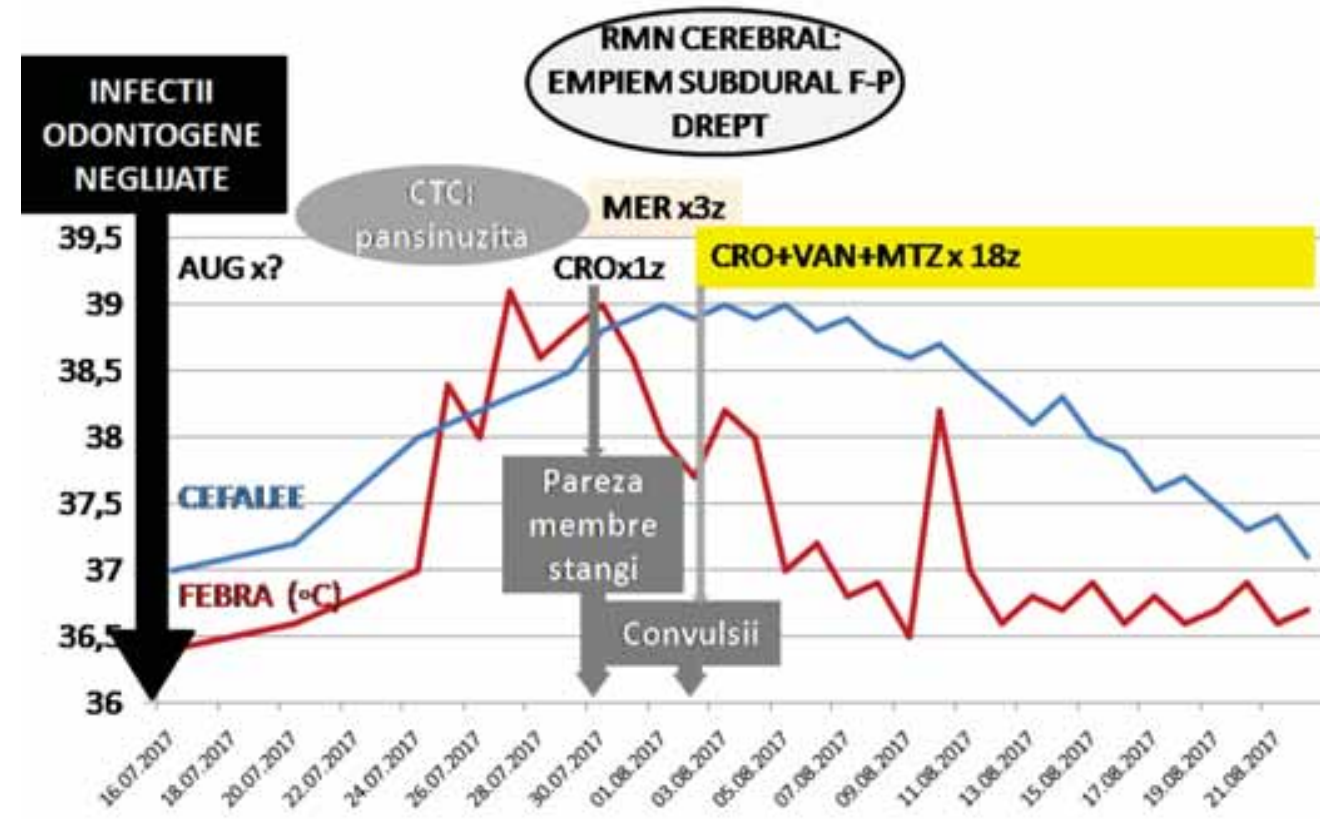

FIGURA 2. §ิ, 20 ani - Evoluția şi tratamentul empiemului subdural

Legenda: MER: Meropenem; CRO: Ceftriaxona; VAN: Vancomicina; MTZ: Metronidazol; F-P: fronto-parietal; CTC: computer tomografie cerebrală; RMN: rezonanță magnetică nucleară; z: zile.

cerebrale, mai ales în cele cu origine odontogenă, dar rata de izolare este mai scăzută din cauza dificultăţilor practice de transport şi cultură anaerobă(7). Rata identificării etiologiei creşte de peste trei ori în cazul analizei aspiratului din empiem prin tehnologia moleculară de secvențiere a ADNului bacterian $16 \mathrm{~S}$ ribozomal, dar această procedură nu poate fi încă utilizată de rutină (8).

Etiologia rinosinuzitei este diferită de a sinuzitei odontogene. În prima etapă a cazului prezentat, examenul CTC nativ a evidenţiat sinuzita maxilară asociată meningitei purulente, a carei etiologie frecventă este reprezentată de Streptococcus pneumoniae, Haemophilus influenzae şi Moraxella catarrhalis. Alegerea Meropenemului pentru terapia inițială a fost justificată de spectrul antibiotic larg, inclusiv pentru pneumococi şi bacili gram negativi, de capacitatea concentrării în doze adecvate la nivelul meningelui şi țesutului cerebral, precum şi de profilul de siguranță favorabil. Totuşi, Meropenemul s-a dovedit ineficient pentru tratamentul empiemul subdural, identificat după 3 zile de evoluție, datorită repetării examenului imagistic. Această situație este explicabilă odată cu evidențierea focarelor dentare şi a istoricului stomatologic, care au orientat către originea odontogenă a sinuzitei. Caracteristica sinuzitei odontogene este etiologia mixtă (germeni aerobi şi anaerobi) şi prezența frec- ventă a Bacteroides spp, natural rezistențe la carbapeneme (9). Schimbarea Meronemului a fost considerată şi în contextul apariţiei convulsiilor. Crizele convulsive fac parte din tabloul clinic obişnuit al meningoencefalitelor, dar pot fi şi reacții secundare la Meronem, deşi acest risc este de numai 0,08\% (10). Evoluția convulsiilor a fost favorabilă cu tratament anticonvulsivant (Carbamazepin), dar pacientul necesită monitorizare şi tratament neurologic de lungă durată.

Anatomic, rădăcinile molarilor superiori sunt situate în proximitatea planşeului sinusului maxilar, favorizează fistulizarea şi extinderea infecției de la nivelul rădăcinilor dentare, mai ales de la al doilea molar, către sinusurile maxilare şi apoi către țesutul cerebral. Ghidurile terapeutice recomandă tratamentul supuraţiilor cerebrale cu asocierea antibioticelor Ceftriaxon, Vancomicin şi Metronidazol, datorită penetrabilității prin bariera hematoencefalică, precum si acoperirii spectrului etiologic al infecțiilor odontogene, reprezentat de asocieri de enterobacteraceae, coci Gram pozitivi, inclusiv pneumococi şi stafilococi cu probleme de rezistență sau coci şi bacili anaerobi.

Diagnosticul colecțiilor cerebrale în primele zile de la constituire poate fi omis de examenul CTC nativ realizat în urgență, necesitând repetarea investigațiilor imagistice, acest scenariu fiind obser- 
vat şi în cazul prezentat (11). Efectul de masă este determinat mai ales de edem şi ischemie, mai puţin de abces. Deşi CTC nativ nu a evidenţiat leziuni localizate cerebrale, prezența imaginilor aerice frontal şi parietal drept, precum şi pareza membrelor stângi, ar fi putut atrage atenția asupra posibilităţii unei sinuzite cu germeni anaerobi şi eroziunilor osoase, anticipând riscul empiemului.

Grosimea empiemului în cazul prezentat a fost de $2,5 \mathrm{~mm}$. Empiemul s-a remis după tratamentul cu antibiotice, fără intervenție chirurgicală. Tratamentul conservativ este permis numai în cazul empiemelor cu dimensiuni mai mici de $1,5 \mathrm{~cm}$ (12), dar în prezent această opțiune este rareori preferată (13). Procedura de aspirație şi identificare microbiologică din aspirat nu a fost disponibilă în centrul nostru, alegerea empirică a terapiei antibiotice bazându-se pe judecata clinică şi pe recomandările ghidurilor terapeutice.

Durata optimă a tratamentului cu antibiotice pentru empiemul subdural nu este precizată, dar majoritatea ghidurilor recomandă cel puțin 4-8 săptămâni, în funcție de evoluție $(1,4)$. Mortalitatea globală în cazurile de empiem subdural variază între 15 şi $25 \%$. Evoluția empiemului cu sursă odontogenă a fost favorabilă în cazul nostru, dar sunt posibile complicații tardive după infecția intracerebrală, pentru care pacientul trebuie monitorizat neurologic. Tratamentul stomatologic complex este necesar pentru asanarea focarelor infecțioase dentare, prevenind recidiva sinuzitei odontogene.

\section{CONCLUZII}

Tratamentul empiric al supurațiilor cerebrale favorizate de infecțiile odontogene trebuie să asocieze şi antibiotice active pentru germeni anaerobi. Indicaţia tratamentului antibiotic conservativ depinde de dimensiunile, localizarea leziunilor şi starea biologică a pacientului. Prognosticul favorabil al empiemului subdural este condiționat de diagnosticul precoce. 